\title{
CELL growth and viability analysis in poli membranes (L-lactic acid-CO-glycolic acid): an in vitro study
}

\author{
Análise do crescimento e viabilidade celular em membranas de poli \\ (L-ácido láctico-CO-ácido glicólico): um estudo in vitro
}

\author{
Daniel Facó da Silveira SANTOS ${ }^{1}$ iD 0000-0002-3524-2419 \\ Jéferson Martins Pereira Lucena FRANCO' ${ }^{1}$ iD 0000-0003-1876-4191 \\ Felipe Gomes XAVIER' ${ }^{1}$ iD 0000-0002-9277-2176 \\ Aguedo ARAGONES ${ }^{2}$ iD 0000-0003-2243-1832 \\ Carlos Clessius Ferreira XAVIER ${ }^{3}$ iD 0000-0003-4805-6743 \\ Antonio Marcos MONTAGNER ${ }^{4}$ iD 0000-0002-4312-0198
}

\begin{abstract}
Objective: Performing an in vitro evaluation of the biological effects on cell growth and viability of fibroblasts in PLGA membranes with and without simvastatin. Methods: Two groups of resorbable synthetic polymeric membranes were used: PLGA, with and without simvastatin, cut into a suitable format to fit to 24 thermometric wells. Fibroblasts were grown on resorbable membranes and evaluated for proliferation and viability at 24, 48 and 72 hours after the beginning of cultivation, being the tests performed in triplicate. For the cell growth analysis, the Trypan blue exclusion method was applied, while cell viability was observed by the MTT test. The results were statistically analyzed applying the Two-Way ANOVA, followed by the Bonferroni test, with 95\% confidence interval and $P$ value smaller than 0.05 was accepted as statistically significant. Results: Statistical difference $(p<0.01)$ was seen between the control group ( $2.16 \times 104 \pm 0.51$ cells) and the PLGA group with simvastatin ( $1.58 \times 104 \pm 0.36$ cells) in the 48 -hour period. After 72 hours, statistical differences $(p<0.001)$ were observed between the PLGA group with simvastatin $(1.66 \times 104 \pm 0.49$ cells) and the PLGA group without simvastatin $(2.25 \times 104 \pm 0.2$ cells $)$ when compared to the control group $(2.81 \times 104 \pm 0.33$ cells $)$ for cell proliferation. Statistical differences $(p<0.05)$ were observed between the control group $(0.27 \pm 0.05)$ and the PLGA group with simvastatin $(0.21 \pm 0.03)$. Likewise, a statistical difference $(p<0.001)$ was seen between the PLGA group without simvastatin $(0.19 \pm 0.02)$ and the control group after 24 hours. In the $48-72$-hour period, statistical differences $(p<0.001)$ were observed between the control group $(0.36 \pm 0.09$ and $0.55 \pm 0.05$, after 48 and 72 hours respectively) and the PLGA group without simvastatin $(0.26 \pm 0.05$ and $0.34 \pm 0.07$, after 48 and 72 hours respectively), as well as in the PLGA group with simvastatin ( $0.27 \pm 0.04$ and $0.31 \pm 0,04$, after 48 and 72 hours respectively) for the cell viability test. Conclusion: The association of simvastatin to PLGA membranes had an inhibitory effect on fibroblast proliferation, as well as induced a reduction in cell viability. Thus, the use of PLGA along with simvastatin may assist in guided bone regeneration.
\end{abstract}

Indexing terms: Fibroblasts. Lactic acid. Simvastatin.

${ }^{1}$ Hospital Geral de Fortaleza, Departamento de Cirurgia Oral e Maxilofacial. Rua Ávila Goularte, 900, Papicu, 60150-160, Fortaleza, CE, Brasil. Correspondência para / Correspondence to: DFS SANTOS. E-mail: <danielsilveirasantos@gmail.com>.

2 Universidade Federal de Santa Catarina, Departamento de Saúde Pública. Florianópolis, SC, Brasil.

${ }^{3}$ Faculdade Fametro, Departamento de Cirurgia Oral e Maxilofacial. Fortaleza, CE, Brasil.

${ }^{4}$ Faculdade São Leopoldo Mandic, Instituto de Pesquisas São Leopoldo Mandic, Implantodontia. Campinas, SP, Brasil.

$\boldsymbol{v} \boldsymbol{v} \boldsymbol{v}$

How to cite this article

Santos DFS, Franco JMPL, Xavier FG, Aragones A, Xavier CCF, Montagner AM. CELL growth and viability analysis in poli membranes (L-LACTIC ACID-CO-GLYCOLIC ACID): an in vitro study. RGO, Rev Gaúch Odontol. 2018;66(4): e20190024. http://dx.doi.org/10.1590/1981-86 372019000243506
} 


\section{RESUMO}

Objetivo: Esse trabalho avaliou, in vitro, os efeitos biológicos no crescimento e viabilidade celular de fibroblastos em membranas de PLGA com e sem sinvastatina. Materiais e métodos: Foram utilizados dois grupos de membranas reabsorvíveis de polímeros sintéticos: PLGA com sinvastantina e sem sinvastantina, recortadas em formato apropriado para adaptar nas placas de 24 wells termométricas. Os fibroblastos foram cultivados em membranas reabsorvíveis, sendo avaliadas em relação à proliferação e viabilidade em 24, 48 e 72 horas após o início do cultivo, os testes foram realizados em triplicata. Para a análise do crescimento celular foi utilizado o método de exclusão vital azul de Tripan, enquanto a viabilidade celular foi observada pelo teste MTT. Os resultados obtidos foram estatisticamente analisados utilizando Two-Way ANOVA, seguido pelo teste de Bonferroni, com intervalo de confiança de 95\% e um valor de $P$ inferior a 0,05 foi aceito como estatisticamente significativo. Resultados: Foi observado diferença estatística ( $p<0,01)$ entre

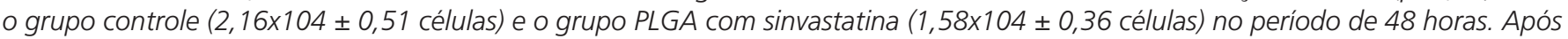
72 horas, diferenças estatísticas $(p<0,001)$ foram observadas entre o grupo PL GA com sinvastatina $(1,66 \times 104 \pm 0,49$ células) e o grupo PLGA sem sinvastatina $(2,25 \times 104 \pm 0,2$ células) em comparação ao grupo controle $(2,81 \times 104 \pm 0,33$ células) quanto a proliferação celular. Diferenças estatísticas $(p<0,05)$ foram observadas entre o grupo controle $(0,27 \pm 0,05)$ e o grupo PLGA com sinvastatina $(0,21 \pm 0,03)$, da mesma forma que, diferença estatística $(p<0,001)$ foram observadas entre o grupo PLGA sem sinvastatina $(0,19 \pm$ $0,02)$ e grupo controle após 24 horas. No período de 48 horas e 72 horas diferenças estatísticas $(p<0,001)$ foram observadas entre o grupo controle $(0,36 \pm 0,09$ e 0,55 0,05, após 48 e 72 horas respectivamente) e o grupo PLGA sem sinvastatina (0,26 \pm 0,05 e

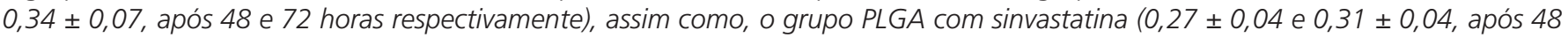
e 72 horas respectivamente) quanto ao teste de viabilidade celular. Conclusão: A associação de sinvastatina às membranas de PLGA apresentou um efeito inibitório na proliferação de fibroblastos, bem como induziu uma redução da viabilidade celular destes, deste modo, sugere-se a utilização de PLGA associado à sinvastatina como uma ferramenta para auxiliar na regeneração óssea guiada.

Termos de indexação: Fibroblastos. Ácido láctico. Sinvastatina.

\section{INTRODUCTION}

Contemporary Implantology has a great need to predict results and present less traumatic surgical techniques for reconstruction and regeneration of tissues lost by pathological, physiological or traumatic processes. Currently, guided bone regeneration (GBR) and guided tissue regeneration (GTR) techniques are frequently applied, with the biological principle of creating a reserved space that facilitates selective cell proliferation and binding. The membranes act as a physical barrier with the purpose of creating spaces, preventing the proliferation of connective and epithelial tissues in bone and/or periodontal defects, stimulating bone and tissue regeneration $[1,2]$.

In dental practice, the GBR and the GTR concepts have been applied since the late 1980's [3]. Although different materials have been investigated for such procedures, resorbable membranes, based on animal collagen and synthetic polymers, are the materials most widely used [4].

Poly (1-lactic acid-co-glycolic acid), PLGA, is a synthetic copolymer of poly lactic acid (PLA) and polyglycolic acid (PGA) that has been used in the production of several therapeutic devices including tissue grafting, surgical suture wires and drug carrier membranes $[5,6]$. It is important to mention that its characteristics are excellent biocompatibility, controlled biodegradability, adjustable degradation rates, mechanical properties, thermal processability and drug controlled release [7]. The PLGA polymers' biodegradable characteristics and biocompatibility, along with handling easiness, have made them an excellent choice for the development of resorbable membranes used in GBR and GTR [8].

The use of PLGA membranes, such as drug carriers, has created new perspectives for bone regeneration, with statins being the most promising drug group. Statins (among them, simvastatin) are irreversible and competitive inhibitors of 3-hydroxy-3-methylglutaryl Coenzyme A (HMG-COA) reductase that initially acts by displacing the natural substrate (HMG-COA) in the cholesterol biosynthetic pathway, reducing the biosynthesis of mevalonate and, consequently, the cholesterol. Recent studies have reported that these drugs have several pleiotropic effects that induce an improvement in the regeneration of bone tissue, since they may change the mechanisms of bone formation and resorption $[9,10]$. However, the correct molecular mechanism of increased bone formation remains unknown. Nevertheless, there are in vitro and in vivo studies reporting that the stimulation of vascular endothelial growth factor (VEGF) and bone morphogenetic proteins 2 (BMP-2) are responsible for the anabolic effects of statins in bone metabolism $[11,12]$.

Therefore, this study aimed at performing an in vitro evaluation of the biological effects of cell growth and viability in PLGA membranes with and without simvastatin. 


\section{METHODS}

The survey was conducted at the São Leopoldo Mandic Dental School and Research Center, campus Campinas, Brazil, in the Cell and Molecular Biology Laboratory, after being approved by the Research Ethics Committee of the São Leopoldo Mandic Dental School and Research Center (Protocol 2015/0393).

\section{Sample}

Two groups of resorbable synthetic polymeric membranes were used: PLGA with simvastatin and PLGA without simvastatin. The membranes were produced from the PLGA Copolymer (Lactic Acid-Co-Glycolic Acid (RESOMERTM Evonik, USA) by the solvent evaporation method. These Aliphatic Esters have the property of being hydrolyzed and degraded by the Krebs cycle, resulting in Carbonic Gas and Water as metabolic products. The degradation time and, hence, absorption is related to the total mass of the membrane. On average, this period may take 90 to 120 days.

PLGA copolymer, in the ratio 3:1 (based polymer lactide: poly (L-Lactic acid-co-trimethylene carbonate), was dissolved in PA chloroform $(10 \% \mathrm{w} / \mathrm{v})$, at room temperature. After the complete dissolution of the polymer, particles of sucrose $(75 \% \mathrm{w} / \mathrm{w})$ ) with granulation of less than $500 \mu \mathrm{m}$ were added. This solution was poured into Medical Grade Silicone molds with dimensions of $2 x$ $8 \times 200 \mathrm{~mm}$ until the total evaporation of the solvent. The membranes were, then, sectioned with a scalpel blade to obtain square samples with $2 \mathrm{~mm}$ thickness and sides with $8 \mathrm{~mm}$. Sucrose was removed using $1 \%$ polyvinyl alcohol solution PS ((C 2 H 4 O) n) in 24-hour baths, followed by 24-hour baths with distilled water under constant stirring. For the samples containing simvastatin (SIM $\geq 97 \%$, high performance liquid chromatography grade, HPLC, solid $M=418.57)$, the drug was diluted $5 \%$ in chloroform (10 ml) to which sucrose (75\%) was added to the polymer already diluted in chloroform. The additional steps for obtaining the membrane with Simvastatin were the same as described above. After the samples' drying, they were sterilized by gamma radiation (20kGy) (CBE EMBRARRAD, Cotia-SP, Brazil)

The membranes were cut into a suitable format to fit in the 24 thermometric well plates, so that the proliferation and cell viability tests could be performed respectively.

\section{Cell lines}

The human fibroblast cell lines were obtained from the Cell Bank of the Cell Culture Laboratory, being provided by (São Leopoldo Mandic Institute and Research Center, Campinas). These cells were previously isolated by the primary culture of human gingival cells removed from volunteer patients by the explant technique.

\section{Cell culture}

Fibroblasts were cultured in Dulbecco's modified Eagle medium (DMEM, Sigma Chemical Co., St. Louis, MO, USA), adding 10\% Fetal Bovine Serum (Cultilab Ltda., Campinas/SP) and $1 \%$ antibiotic solution - antimycotic (Sigma Chemical Co., St. Louis, MO, USA), kept at $37^{\circ} \mathrm{C}$ temperature, humidified atmosphere containing 5\% CO2.

To maintain the cell viability, all procedures were performed in a laminar flow hood for the sterility of the materials and substances used for cell culture. The monitoring of cell growth was performed every 24 hours, using inverted phase microscope, and the culture medium was changed at 2 and 3 days. After reaching confluency, the cells were plated at 110 cells $/ \mathrm{mm} 2$ density in 24 well plates for cell proliferation and viability evaluation. As a controlling method, the cells were plated in polystyrene not containing the material studied.

\section{Cell count}

For the proliferation evaluation, the cells were counted at 24, 48 and 72 hour after culturing the membranes studied. Then, two groups were used with resorbable synthetic membranes: PLGA with simvastatin and PLGA without simvastatin. The medium was removed from the plate and the cells were washed with PBS (phosphate buffer solution), pH 7.0. Then, the cells were enzymatically removed from the plate with $500 \mu \mathrm{L}$ Trypsin at $37^{\circ} \mathrm{C}$ for 5 minutes. $10 \mu \mathrm{L}$ of cell suspension were, then, removed and mixed with $10 \mu \mathrm{L}$ of Tripan blue (for cytotoxicity assessment) and, $10 \mu \mathrm{L}$ were placed in a hemocytometer (Neubauer Chamber, Fisher Scientific, Pittsburgh, PA, USA) and taken to inverted microscope (Nikon, Eclipse TS100) for counting and observation of the cell growth curvature.

The total number of cells was obtained by the following equation: 
Total Number of Cells $=\frac{\left.\text { (Number of cells counted } \mathrm{x} \text { Initial Volume } \mathrm{x} \text { Dilution } \times 10^{4}\right)}{(\text { Number of squares used for counting) }}$

All the experiments were done in triplicates (3 wells for each membrane and control cells).

\section{Cytotoxicity evaluation (MTT)}

Cell cultures were tested for cell viability using the 3- [4,5-Dimethyl-thiazol-2-yl) -2,5-diphenyl-tetrazole (MTT) assay. This assay evaluates the capability of metabolically active cells to reduce MTT by converting the tetrazolium yellow salts to purple formazan crystals and, therefore, the ability of the viable cells to cleave the tetrazole ring present in MTT by the action of enzymes dehydrogenases present in the active mitochondria, forming formazan crystals. In the cytotoxicity assay, 110 cells/mm2 were used in 24 well plates, incubated for a period of 24, 48 and 72 hour at $37^{\circ} \mathrm{C}$. Then, $540 \mu \mathrm{L}$ of DMEM culture medium and $60 \mu \mathrm{L}$ of the MTT solution ( $5 \mathrm{mg} / \mathrm{mL}$ - Sigma, USA) were added under the membranes and control, being incubated for 3 hours at $37^{\circ} \mathrm{C}$. After the total incubation period, the solution was removed and $600 \mu \mathrm{L}$ of $10 \%$ DMSO (dimethyl sulfoxide) solution was added.

After the crystals solubilization, the quantification was performed on a ELX800 microplate reader (Epoch Biotek Instruments, Inc) at $590 \mathrm{~nm}$, obtaining the absorbance measurements.

\section{Statistical analysis}

Results were expressed as mean \pm E.P.M. $(n=6)$. Statistical analysis between the groups was performed applying the Two-way (ANOVA), followed by the Bonferroni test, with a 95\% confidence interval, being $p<0.05$ accepted as statistically significant.

\section{RESULTS}

Considering the cell proliferation test, evaluating the average number of cells obtained in the groups, it was seen that the control group showed higher cell proliferation ( $p<0.001$ ) than the PLGA experimental group with simvastatin, after 48 hours, and the PLGA group without simvastatin, after 72 hours. On average of the three lines, it was observed that the PLGA with simvastatin and the
PLGA without simvastatin presented similar results. At 24 hours, despite the higher cell proliferation in the control group $(1.68 \times 104 \pm 0.36$ cells $)$, there was no statistical difference between the PLGA group without simvastatin $(1.46 \times 104 \pm 0.44$ cells $)$ and the PLGA group with simvastatin $(1.40 \times 104 \pm 0.72$ cells). At 48 hours, statistical difference $(p<0.01)$ was observed between the control group $(2.16 \times 104 \pm 0.51$ cells $)$ and the PLGA group with simvastatin $(1.58 \times 104 \pm 0.36$ cells). Statistical differences $(p<0.001)$ were also observed after 72 hours between the PLGA group with simvastatin $(1.66 \times 104 \pm 0.49$ cells $)$ and the PLGA group without simvastatin $(2.25 \times 104 \pm 0.2$ cells $)$ compared to the group control $(2.81 \times 104 \pm 0.33$ cells $)$. Therefore, PLGA membranes with simvastatin showed less cellular proliferation over time, when compared to PLGA membranes without simvastatin and the control group. The data are shown in figure 1.

\section{DISCUSSION}

Bone defects are a challenge to Dentistry, especially in rehabilitation specialties, such as Implantology.

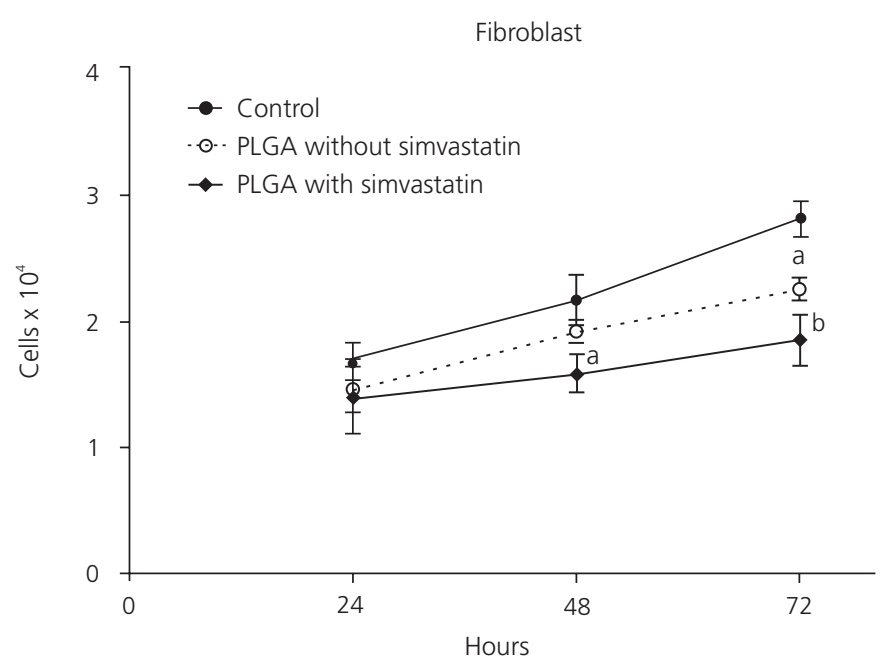

Figure 1. Evaluation of cell proliferation at 24, 48 and 72 hours. Values are expressed as mean ( \pm E.P.M). The letter ' $a$ ' indicates statistical difference when compared to the control group $(p<0.01)$ and the letter ' $b$ ' indicates statistical difference between the PLGA membranes with simvastatin and PLGA membranes without simvastatin compared to the control group $(p<0.001)$. Two-way ANOVA followed by the Bonferroni test. 


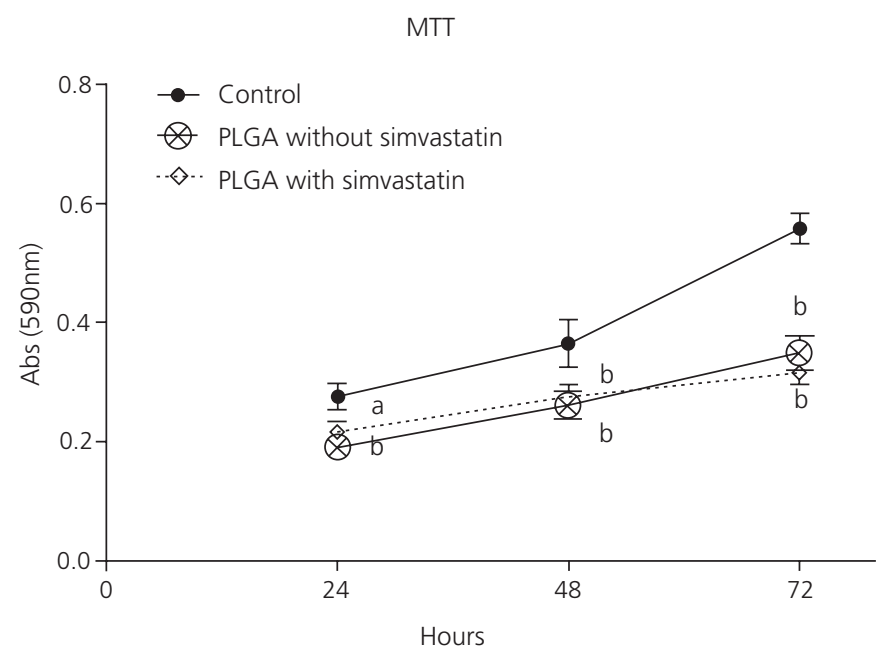

Figure 2. Cell viability test (MTT) at 24,48 and 72 hours. Values are expressed as mean ( \pm E.P.M). The letter ' $a$ ' indicates statistical difference when compared to the control group $(p<0.05)$, and the letter ' $b$ ' indicates statistical difference compared to the control group $(p<0.001)$. Two-Way ANOVA followed by the Bonferroni test.

The success of treatments depends on the quantity and quality of bone availability. Thus, grafting, for bone tissue gain, arose as an alternative to overcome such difficulty. It is important to mention that, uncontrolled resorption, especially of the autogenous graft, requires more effective materials for bone regeneration [13].

Resorbable and non-resorbable membranes are widely used in clinical practice to assist in the regeneration process of soft and hard tissues, being a viable alternative for the correction of tissue defects. However, the membranes should present some characteristics to be effective such as biocompatibility, physical and mechanical properties favoring its placement in human beings, good resistance and proper degradation medium not causing tissue neoformation [14]. Among the several membranes available in the market, the PLGA membrane stands out as a polymer with high structural strength and biocompatibility, as well as showing a great potential as a drug carrier [15].

In the present study, it was observed that the use of PLGA membranes was able to reduce fibroblast proliferation over a period of 72 hours, indicating that such membrane may reduce the formation of fibrous tissue, corroborating with the findings of Shen et al. [16], who demonstrated that PLGA membranes treated with carbon dioxide (CO2) plasma were effective in inhibiting fibroblast growth factors [16]. In addition to the inhibitory effect on the cell proliferation of fibroblasts, the present work showed that the PLGA membrane induces a decrease of fibroblast viability.

Several drugs are used as auxiliaries to tissue and bone regeneration, such as the simvastatin. In the literature, several studies have reported evidences on the efficacy of this statin to bone regeneration $[17,18]$. In our study, the tests performed showed that PLGA membranes with simvastatin were more effective in inhibiting fibroblasts, decreasing the viability of the remaining fibroblasts at all times. Wu et al. [19] concluded that the local application of simvastatin through a PLGA membrane promoted bone neoformation in rat alveolus after exodontics, suggesting the relation of this result to the osteoinductive and antiresorptive properties of simvastatin.

In view of the results found in here, it can be suggested the association of simvastatin to PLGA membranes in GBR. Nath et al. [20] have demonstrated that PLGA microspheres can be used as simvastatin carriers for bone regeneration, being an effective system for the regeneration of bone tissue. The literature shows that, when working with PLGA nanoparticles as drug carriers, there is a linear relationship between the polymer concentration and the nanoparticle volume with different solvents [21].

Aiming at making the association of simvastatin to PLGA membranes more effective, it is necessary to emphasize the importance of drug release just on the surface that will be in contact with the bone tissue, reducing the formation of fibrous tissue in the bone defect and stimulating the osteogenic neoformation (figure 3). This can be achieved due to the easiness of working with PLGA as a carrier of several types of drugs and at different scales (nanoparticles, microparticles and membranes) [15].

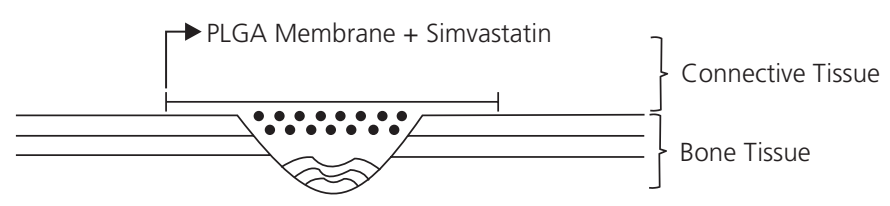

Figure 3. PLGA membrane releasing simvastatin only on the surface in contact with bone tissue/defect, stimulating bone neoformation and inhibiting the proliferation of fibrous tissue. 


\section{CONCLUSION}

Based on the experimental protocols adopted, it is suggested that simvastatin can be successfully incorporated to PLGA membranes for drug delivery at the surgical site, having the ability to inhibit fibroblast proliferation and reduce the viability of such cells. The inhibitory effect of proliferation and reduction of PLGA cell viability was enhanced after the addition of simvastatin to the membrane, in which the effects were evaluated up to 72 hours.

\section{Collaborators}

DFS SANTOS, conception and design of study/review/ case series, acquisition of data: laboratory or clinical/literature search, analysis and interpretation of data collected, drafting of article and/or critical revision and final approval and guarantor of manuscript. JMPL FRANCO, FG XAVIER, A ARAGONES, CCF XAVIER and AM MONTAGNER, conception and design of study/ review/case series, drafting of article and/or critical revision and final approval and guarantor of manuscript.

\section{REFERENCES}

1. DaiY, XiaY, Chen HB, LiN, Chen G, Zhang FM, etal. Optimization of sterilization methods for electrospun poly ( $\varepsilon$-caprolactone) to enhance pre-osteoblast cell behaviors for guided bone regeneration. J Bioact Compat Polym. 2016;31(2):152-66. https://doi.org/10.1177/0883911515598795

2. Marques MS, Zepon KM, Petronilho FC, Soldi V, Kanis LA. Characterization of membranes based on cellulose acetate butyrate/poly (caprolactone) triol/doxycycline and their potential for guided bone regeneration application. Mater Sci Eng C Mater Biol Appl. 2017;76:365-373. https://doi. org/10.1016/j.msec.2017.03.095

3. Suárez-López del Amo F, Monje A, Padial-Molina M, Tang Z, Wang HL. Biologic agents for periodontal regeneration and implant site development. Biomed Res Int. 2015;2015:957518. https://doi.org/10.1155/2015/957518.

4. Gruber R, Stadlinger B, Terheyden H. Cell-to-cell communication in guided bone regeneration: molecular and cellular mechanisms. Clin Oral Implants Res. 2017 Sep;28(9):1139-1146. https://doi. org/10.1111/clr. 12929

5. Ulery BD, Nair LS, Laurencin CT. Biomedical applications of biodegradable polymers. J Polym Sci Part B Polym Phys. 2011;49(12):832-64. https://doi.org/10.1002/polb.22259

6. Liu SJ, Kau YC, Chou C, Chen JK, Wu RH, Yeh WL. Electrospun PLGA/collagen nanofibrous membrane as early-stage wound dressing. J Membr Sci. 2010;355:53-9. https://doi.org/10. 1016/j.memsci.2010.03.012

7. Makadia HK, Siegel SJ. Poly lactic-co-glycolic acid (PLGA) as biodegradable controlled drug delivery carrier. Polymers (Basel). 2011;3(3):1377-97.

8. Sun X, Xu C, Wu G, Ye Q, Wang C. Poly (Lactic-Co-Glycolic Acid): Applications and Future Prospects for Periodontal Tissue Regeneration. Polymers (Basel). 2017;9(6). pii: E189. https://doi.org/10.3390/polym9060189

9. Tian FM, Li SY, Yang K, Luo Y, Dai MW, Liu GY, Zhang L. Orally administered simvastatin partially preserves lumbar vertebral bone mass but not integrity of intervertebral discs in ovariectomized rats. Exp Ther Med. 2017;13(3):877-884. https://doi.org/10.3892/etm.2017.4043

10. Mendes Junior D, Domingues JA, Hausen MA, Cattani SM, Aragones A, Oliveira AL, Duek EA. Study of mesenchymal stem cells cultured on a poly (lactic-co-glycolic acid) scaffold containing simvastatin for bone healing. JABFM. 2017;15(2);e133-e141. https://doi.org/10.5301/jabfm.5000 338

11. Rashidi H, Ellis MJ, Cartmell SH, Chaudhuri JB. Simvastatin release from poly (lactide-co-glycolide) membrane scaffolds. Polymers. 2010;2(4):709-718. https://doi.org/10.3390/polym 2040709

12. Ishihara T, Miyazaki M, Notani N, Kanezaki S, Kawano M, Tsumura H. Locally applied simvastatin promotes bone formation in a rat model of spinal fusion. J Orthop Res. 2017 Sep;35(9):1942-1948. https://doi.org/10.1002/jor.23479. 2017;35:1942-8

13. Chen G, Xia Y, Lu X, Zhou X, Zhang F, Gu N. Effects of surface functionalization of PLGA membranes for guided bone regeneration on proliferation and behavior of osteoblasts. J Biomed Mater Res A. 2013;101(1):44-53. https://doi.org/10. 1002/jbm.a.34298

14. Bottino MC, Thomas V, Schmidt G, Vohra YK, Chu TMG, KowolikMJ, Janowski GM. Recentadvances in the development of GTR/GBR membranes for periodontal regeneration-a materials perspective. Dental Mater. 2012;28(7):703-21. https:// doi. org/10.1016/j.dental.2012.04.022

15. Makadia HK, Siegel SJ. Poly lactic-co-glycolic acid (PLGA) as biodegradable controlled drug delivery carrier. Polymers (Basel). 2011;3(3):1377-97.

16. Shen $\mathrm{H}, \mathrm{Hu} X$, Bei J, Wang S. The immobilization of basic fibroblast growth factor on plasma-treated poly (lactide-coglycolide). Biomaterials. 2008;29(15):2388-99. https://doi. org/10.1016/j.biomaterials.2008.02.008

17. Park JB. The use of simvastatin in bone regeneration. Med Oral Patol Oral Cir Bucal. 2009;14(9):e485-8.

18. Papadimitriou K, Karkavelas G, Vouros I, Kessopoulou E, Konstantinidis A. Effects of local application of simvastatin on bone regeneration in femoral bone defects in rabbit. J Cranio Maxill Surg. 2015;43(2):232-7. https://doi.org/10.1016/j.jcms. 2014.11.011 
19. Wu Z, Liu C, Zang G, Sun H. The effect of simvastatin on remodelling of the alveolar bone following tooth extraction. Int J Oral Maxillofac Surg. 2008;37(2):170-6. https://doi. org/10.1016/j.ijom.2007.06.018

20. Nath SD, Son S, Sadiasa A, Min YK, Lee BT. Preparation and characterization of PLGA microspheres by the electrospraying method for delivering simvastatin for bone regeneration. Int J Pharm. 2013;443(1-2):87-94. https://doi.org/10.1016/j.jppharm. 2012.12.037
21. Cheng J, Teply BA, Sherifi I, Sung J, Luther G, Gu FX, et al Formulation of functionalized PLGA-PEG nanoparticles for in vivo targeted drug delivery. Biomaterials. 2007;28(5):869-76. https://doi.org/10.1016/j.biomaterials.2006.09.047

Received on: 7/7/2018

Final version resubmitted on: 6/11/2018

Approved on: 4/12/2018 